\title{
Retratos sem retoques? A experiência de fotobahia e o lugar social da fotografia*
}

\section{¿Retratos sin retoques? La experiencia de fotobahia y el lugar social de la fotografía}

Elson de Assis Rabelo ${ }^{1}$

Rafaela Novaes Feitoza ${ }^{2}$ 


\section{Resumo}

Como primeiros resultados de pesquisa, analisamos, neste texto, a ocorrência do gênero do retrato nos catálogos intitulados "FotoBahia", publicados em Salvador, pelo Grupo de Fotógrafos da Bahia, entre 1979 e 1984. Situando essa produção na história da fotografia documental e do fotojornalismo da segunda metade do século $X X$, tomamos as imagens e os textos que lhes acompanharam e que serviam para veicular as práticas do referido Grupo como ferramentas de trabalho para a compreensão de como o retrato foi pensado como forma visual e como metáfora para o lugar da fotografia. Abordamos, ainda, aspectos da constituição e da margem de experimentação de um tipo de imagem cuja produção desembocava nas controvérsias travadas em torno do papel e dos usos da fotografia, no final da ditadura militar.

Palavras-chave: Fotografia baiana; FotoBahia; Retrato; Fotografia documental.

\section{Abstract}

Analizamos la ocurrencia del género del retrato en os catálogos titulados "FotoBahia", publicados en la ciudad de Salvador, por el Grupo de Fotógrafos de Bahia, en Brasil, entre 1979 y 1984. Al situar dicha producción en la historia de la fotografía documental y del fotoperiodismo de la segunda mitad del siglo XX, nos acercamos de dichas imágenes y de los textos que les acompañaron y que vehiculaban las prácticas de dicho Grupo como herramientas de trabajo para la interpretación sobre como el retrato fue pensado como forma visual y como metáfora para el lugar social de la fotografía. Investigamos aspectos de la constitución y del margen de experimentación de un tipo de imágenes cuya producción atingía las controversias planteadas alrededor del papel y de los usos de la fotografía, en fines de la dictadura militar brasileña.

Palabras llave: Fotografía de Bahia; FotoBahia; Retrato; Fotografía documental.

ISSN: 2175-2346

1elson_rabelo@hotmail.com

2 rafa.n.f@hotmail.com 


\section{INTRODUÇÃO}

Em linhas gerais, o retrato pode ser caracterizado como uma imagem de uma ou mais pessoas, posada ou não, que busca a captura de uma expressão, de um gesto, de um momento daqueles que são retratados. Por todos os atributos que são conferidos culturalmente ao corpo, e especialmente ao rosto, como signos de uma presença que substituiria uma ausência, através da imagem, a expressão desse momento poderá ser tida como representativa de dado indivíduo ou grupo. Daí, origina-se toda uma dimensão afetiva e memorativa construída em torno dos retratos dos entes queridos ou daqueles que adquiriram importância para determinado contexto. Por outro lado, um retrato nos permitiria observar não só tais indivíduos e grupos, mas também o espaço onde eles se encontram e até mesmo a sua condição social, por meio dos elementos cênicos que lhe constituem, como as indumentárias, as poses e o gestual.

O retrato, além disso, é uma das formas mais recorrentes na história da arte ocidental, a começar pelas pinturas, no Renascimento, encomendadas por famílias nobres a pintores renomados. Possuir um retrato, então, era sinônimo de nobreza e de pertença às classes que tinham condições de mandar pintar retratos pessoais ou familiares, e, assim como nos brasões nobiliárquicos, a própria composição formal, as dimensões e a disposição dos elementos e personagens, na imagem, deveriam conotar status social, a fim de afirmar esse lugar no imaginário ou mesmo de conjurar a morte do representado, por meio de sua simbolização (WARBURG, 2013; BELTING, 2014, p. 151-180). Quando a fotografia surgiu, no século XIX, essa característica elitista permaneceu por algum tempo, até que os aparatos fotográficos tenham se tornado responsáveis por transformar mais explicitamente o retrato em mercadoria e fazê-lo acessivel a diferentes estratos sociais e passível de usos diversos.

Desse modo, o mesmo gênero de imagens, herdeiro da história da arte ocidental, prestou-se aos diferentes registros documentais, à produção artística, à imprensa ilustrada nascente, à reprodução e representação dos habitus de classe, ao disciplinamento, ao escrutínio e inclusive à racialização dos corpos por parte do Estado e de saberes como a medicina, a psiquiatria e a antropologia criminal (TAGG, 2005; FREUND, 2011, p. 79-86, KOUTSOUKOS, 2010; DIDI-HUBERMAN, 2007). Embora cada vez mais entendido como a captura de um momento fugaz, dadas as possibilidades surgidas com o incremento tecnológico que deu vazão ao surgimento do flagrante, ao longo do século $X X$, o retrato fotográfico não cessou de sofrer reinvenções das mais diversas, especialmente por parte do fotojornalismo, que o desdobrou para as ruas, o meio rural, os cenários de guerra e as circunstâncias sociais mais diversas (DEL CASTILLO TRONCOSO, 2011, p. 155-164).

Neste texto, trazemos os primeiros resultados de uma pesquisa na qual analisamos desdobramentos e implicações da produção de fotografias em uma publicação que não se definia exatamente nem como fotojornalística nem como artística, mas que propunha a valorização e a ampliação dos espaços sociais da fotografia e do fotógrafo. Trata-se do catálogo intitulado "FotoBahia", surgido como resultado de exposições e atividades formativas organizadas pelo Grupo de Fotógrafos da Bahia, a partir de 1978. Na encruzilhada entre diferentes tratamentos dados à imagem fotográfica, por diversos fotógrafos, definiu-se ali um desses momentos de reinvenção 
do gênero do retrato, que dialogava com ou mesmo deslocava certa tradição fotográfica, como a fotografia documental e a chamada fotografia artística baianas.

Em termos metodológicos, fazemos um recorte de alguns retratos fotográficos que aparecem nos catálogos daqueles anos para analisá-los no entrecruzamento com a leitura dos textos que lhes acompanhavam, como os comentários introdutórios feitos por jornalistas, para discutir os pressupostos de como eram entendidos os retratos e a própria fotografia, num momento particular de engajamento e redefinição do lugar social do fotógrafo. Utilizamos em nossa análise, também, as entrevistas que fizemos com participantes do Grupo e que nos servirão não apenas para ler propriamente as fotos, mas para indicar como os fotógrafos rememoram seus processos de criação e edição, em dado momento de sua trajetória, e a interpretação que fazem, no tempo presente, a respeito daquele passado recente (SANTHIAGO, 2013).

\section{FotoBahia e o projeto de "revelar as realidades de um povo"}

No final dos anos 1970, um grupo de fotógrafos se reúne em Salvador, com o objetivo de promover a prática da fotografia sem restrições em relação ao campo de atuação, pretendendo também cultivar olhares sobre a cultura e a sociedade baianas vindos de dentro da própria Bahia, diferentemente da tradição de fotógrafos viajantes e observadores externos que por ali haviam passado, desde o século XIX, como o famoso etnólogo francês Pierre Verger, que se estabelecera naquela capital (FALCÓN, 2006). Entre aproximadamente 1978 e 1984, no período de reabertura política do país, ao final da ditadura militar, o chamado Grupo de Fotógrafos da Bahia surgiu liderado pelo mineiro Aristides Alves, fotojornalista, e reuniu fotógrafos e fotógrafas de trajetórias distintas, como, por exemplo: o fotógrafo documental Adenor Gondim, o arquiteto Silvio Robatto, o psicólogo Rino Marconi, os fotojornalistas Valdir Argolo, Milton Mendes e Fred Passos, outros cujos nomes iam se estabelecendo pela dedicação à fotografia artística, como Mário Cravo Neto, Bauer Sá e Euvaldo Macedo Filho, fotógrafos iniciantes como Célia Aguiar e Maria Sampaio, e aqueles conhecidos como "artistas fotógrafos", como Juraci Dórea e Juarez Paraíso, que já se estavam consagrando no meio artístico por trabalhar com diferentes suportes em seus processos criativos, dentre outros tantos como Antonio Saturnino, Arestides Baptista, Arlete Soares, Vicente Sampaio, Artur Ikissima, David Glat, Iraildes Nascimento, Isabel Gouveia, Jamison Pedra, Miguel Rio Branco, Rosa Maria, em suma, uma constelação de fotógrafos do interior e da capital baiana, iniciantes e experientes ${ }^{1}$.

Pela própria dinâmica de trabalho em grupo, este não era fixo e as atividades se davam na forma de partilha e curadoria coletiva, quando das exposições de seus trabalhos. O editorial de um pequeno jornal criado e publicado pelo grupo em 1981 informa que de 1978 para 1979, por exemplo, aumentou de 50 para 76 o número de fotógrafos participantes. Embora houvesse um núcleo mais ou menos fixo na organização dos seminários, oficinas e publicações, a ocorrência de integrantes variava muito a cada catálogo, especialmente porque, para confecção desses cadernos, não eram todos que enviavam fotos. Também conhecido por FotoBahia, que era o nome

1 Para um panorama mais abrangente dos nomes dos fotógrafos e de seu período de atuação, ver ALVES, Aristides (coord.). A Fotografia na Bahia (1939-2006). Salvador: Asa Foto Ltda., 2006. 
geral de suas exposições, do referido jornal e do catálogo de fotos, o grupo foi responsável por um conjunto de iniciativas que terminaram por se voltar à veiculação pública de seus trabalhos, ao passo que as imagens produzidas passaram a ser consideradas como tendo a missão de "revelar as realidades de um povo", como dizia um texto de apresentação.

Cumpre lembrar que, após os mais duros anos de repressão e perseguição da parte do Estado, aquele momento foi marcado, no Brasil inteiro, pela recuperação da atuação dos sindicatos de várias categorias profissionais, pela organização de grupos e coletivos de produção cultural, e, especialmente, no que se refere à fotografia, pela luta para a profissionalização do fotógrafo e a atribuição do crédito autoral nos veículos de imprensa (MONTEIRO, 2015). No mundo inteiro, aliás, após o período de grande produção da imprensa ilustrada a encargo das redações, os fotógrafos passaram a se associar entre si para criar agências independentes, com o fito de estabelecer valores mínimos de mercado para seus produtos e serviços (SOUSA; 2004, p. 151197). Resultado disso, no meio fotográfico brasileiro, foi o surgimento, já nos anos 1980, de políticas públicas específicas, como a criação do Núcleo de Fotografia na Fundação Nacional de Arte (FUNARTE) (MAUAD; LOUZADA; SOUZA JÚNIOR, 2014).

As atividades do Grupo de Fotógrafos da Bahia se inseriam nessa movimentação, em níveis local e regional, tendo, com o passar dos anos, chegado a contar com a participação de fotógrafos e estudiosos da fotografia de outros lugares, como Nair Benedicto e Milton Guran, e de instituições como a Escola de Belas Artes da Universidade Federal da Bahia (UFBA) e a Sociedade Brasileira para o Progresso da Ciência (SBPC), com cujo apoio era promovidas as oficinas e os seminários de caráter aberto a todos os interessados, bem como exposições em diversos espaços expositivos, como o Foyer do Teatro Castro Alves e a própria UFBA. O catálogo de 1984 indica que a exposição principal, a última e maior de todos os anos de existência do Grupo, ocorrera naquele ano de 22 de novembro a 13 de dezembro, no Museu de Arte Moderna da Bahia (MAM), com encontro de fotógrafos, mostras de audiovisuais, oficinas de fotojornalismo, fotopublicidade e sobre fotografia e educação, além das atividades do Projeto FotoViva, desenvolvido no Pelourinho com crianças de rua, a partir da iniciativa de Rino Marconi.

A exposição no MAM ainda teve patrocínio do Ministério da Educação e Cultura, através da FUNARTE, e do Instituto Nacional da Foto, como também colaboração da Fundação Cultural do Estado da Bahia. Alçar um espaço como o Museu, embora não fosse o objetivo inicial da formação do Grupo, parecia a demarcação de um lugar social considerável, a par de outro movimento sub-reptício que vinha se dando em outros lugares do país, como, por exemplo, no Museu de Arte Contemporânea de São Paulo, com o estabelecimento de critérios estéticos que incluíam a fotografia como objeto de exposição, e que foram colocados internacionalmente pela arte moderna, desde os anos 1940, e pela arte contemporânea, com a própria ideia das bienais de arte que havia chegado ao Brasil (COSTA, 2008). Seja diretamente como "arte" ou como suporte para a criação artística, a chegada da fotografia ao espaço de arte acabou por ter sido encarada de maneira controversa, pelos próprios integrantes 
do Grupo².

Apesar disso, no entanto, nossa análise se deterá, aqui, na notável presença do gênero do retrato nos catálogos cujo título acabaram por dar nome ao Grupo e cuja heterogeneidade das imagens dava a perceber que havia uma relativa margem de experimentação pelos participantes. Nessas imagens, à primeira vista, observando quem são os indivíduos e grupos retratados pelos fotógrafos, vemos jovens, idosos, trabalhadores, negros e brancos, militares, pescadores, mulheres, religiosos, moradores de rua, o que confirma a vocação abrangente que FotoBahia se atribuía, em termos de temas e situações que seriam alvo da prática fotográfica. Grande parte desses retratos remetem à poética do documental, que havia caracterizado a fotografia baiana do passado recente, como o notável fotógrafo Voltaire Fraga. No entanto, um olhar mais cuidadoso pode encontrar, atentado para a duração das atividades do Grupo, certas inovações formais que dialogavam com outras referências e que, portanto, escavavam outro universo de significados e usos para aquelas imagens.

\section{FotoBahia e o fotojornalismo}

Ter sido criado por iniciativa de um fotojornalista foi um detalhe decisivo para o posicionamento que o Grupo de Fotógrafos da Bahia assumiu localmente na luta pelo direito autoral que marcou o final dos anos 1970 e início dos anos 1980. Um fragmento de memória de Aristides Alves ajuda a entender aquele momento:

[...] quando começou o FotoBahia, a história da fotografia, não só baiana mas
do Brasil, a fotografia que estava em evidência era o fotojornalismo, porque era
uma resistência à ditadura, era uma forma de você estar tentando fazer denúncia
social, era um tipo de fotografia muito valorizado, era uma forma que você tinha
de estar resistindo também, e aqui na Bahia também se fazia uma foto documen-
tal, mas um documental ligado ainda a uma pauta de revista. [...] FotoBahia pega
esse momento crítico de 78, dessa passagem do fotojornalismo, mas já começa,
em 78 e 79 , já começa o movimento da fotografia, que sai da pauta de jornais,
essa coisa toda, e ela já entra em dois outros níveis. Um que é a fotografia autoral.
Então, os fotógrafos passam a eleger alguns temas e a desenvolvê-los. E a foto
começa a se dar também dentro da Universidade, da Escola de Belas Artes, aqui
(ALVES, 2015).

Para situar a fala de Aristides Alves, indiquemos o que vivia o fotojornalismo brasileiro de então. Consolidado a partir dos anos 1950 e marcado, quanto à forma, pelo estabelecimento dos padrões editoriais de mercado, como aqueles colocados pela revista $O$ Cruzeiro e que definiram a própria relação linear entre imagem e texto, e, quanto aos seus conteúdos, após o golpe civil-militar de 1964, pelos constrangimentos da censura e com a agenda própria a uma "descoberta do Brasil", o fotojornalismo procurava dar visibilidade a uma diversidade de práticas culturais e recortes sociais desconhecidos nos grandes centros. A partir de O Cruzeiro, passando por Realidade, Manchete e os jornais locais de média e grande circulação, e assumindo uma visão

2 As falas nas entrevistas indicam uma delicada e às vezes amistosa controvérsia entre os integrantes do Grupo sobre o estatuto da fotografia enquanto arte ou documentação social, num debate que se tornou clichê na história da fotografia, e que, nesse caso em particular, contrariava ou confirmava a trajetória dos fotógrafos, inclusive daqueles que passaram pelo fotojornalismo. A categoria do "artista-fotógrafo" que comparece a essas falas é um exemplo de como se procurava criar critérios e classificar imagens e seus produtores, no interior do Grupo. De todo modo, destaca-se o valor que eles atribuem ao trabalho autoral e abertamente expressivo. 
humanista da sociedade que era tendência internacional, serão produzidas matérias temáticas sobre os diferentes espaços geográficos brasileiros, como a Amazônia e o Nordeste, o cotidiano da política e a transformação da sociedade com a chegada de novidades tecnológicas como a televisão, plasmando, assim, imagens das contradições do Brasil moderno. A incorporação das fotografias coloridas e a definição de uma diretoria de arte, nas redações, viriam a constituir perfis cada vez mais especializados para a constituição da informação a partir da editoração e diagramação das imagens (COSTA, 1998; MIRA, 1997).

No entanto, nos anos 1970, de acordo com certa interpretação, o principal problema do fotojornalismo brasileiro era a censura (KOSSOY, 2007, p. 124-127), que explicaria a necessidade de fazer a denúncia social, referida no depoimento de Alves, nem que fosse de maneira indireta, para além da linguagem permitida, isto é, uma denúncia que fosse social, mas não abertamente política. Assim, na tradição da concerned photography, ou "fotografia engajada", surgida na geração documental estadunidense nos anos 1930, uma importante possibilidade de trabalho era dar a ver os agentes sociais mais miseráveis e seus problemas sociais. A fotografia enquanto registro partiria, então, da crença no impacto que ela poderia causar junto ao público, terminando por colocar o fotógrafo na encruzilhada entre banalizar ou construir certa sensibilidade sobre as questões sociais (SOUSA, 2004, p. 123-180; FONTCUBERTA, 2011). Esta seria a característica mais apropriada à fotografia de denúncia, por chamar aquele que visualiza à reflexão, com base em um compromisso também da parte do veículo onde a imagem circula, compromisso que passava pela seleção de legendas, manchetes e textos que acompanhavam as imagens e que por vezes disputavam com ela espaço de leitura e a construção de sentido nas páginas (GROBET, 2006).

Se levamos em consideração essas premissas, vemos, por exemplo, na leitura crítica da jornalista Mariluce Moura, que abre o catálogo FotoBahia do ano de 1983, um incômodo com o excesso de denúncia social nas fotografias, excesso que, segundo ela, parecia predominante nos trabalhos daquele ano:

As fotos de Fotobahia 1983: desfila diante de mim uma legião de crianças pobres, olhos muito abertos de susto e perplexidade. Cenas de favela. Barracos semi-destruídos. A mesma visão de pobreza repetida à exaustão. Me vem imediatamente à lembrança um trecho de uma matéria que escrevi para a Fotobahia 80: 'Sofrida, torturada, paupérrima, suja e triste - assim é a Salvador que salta das fotografias que estão expostas na Fotobahia 80 (...) E diante do retrato da miséria insistentemente refeito, pode nascer em qualquer pessoa uma indagação quase natural: por que, dentro de uma realidade tão complexa, como é a de Salvador, é esse o tema que atrai o olhar e provoca uma sensibilidade da maioria dos fotógrafos presentes na mostra?' (MOURA, 1983). 


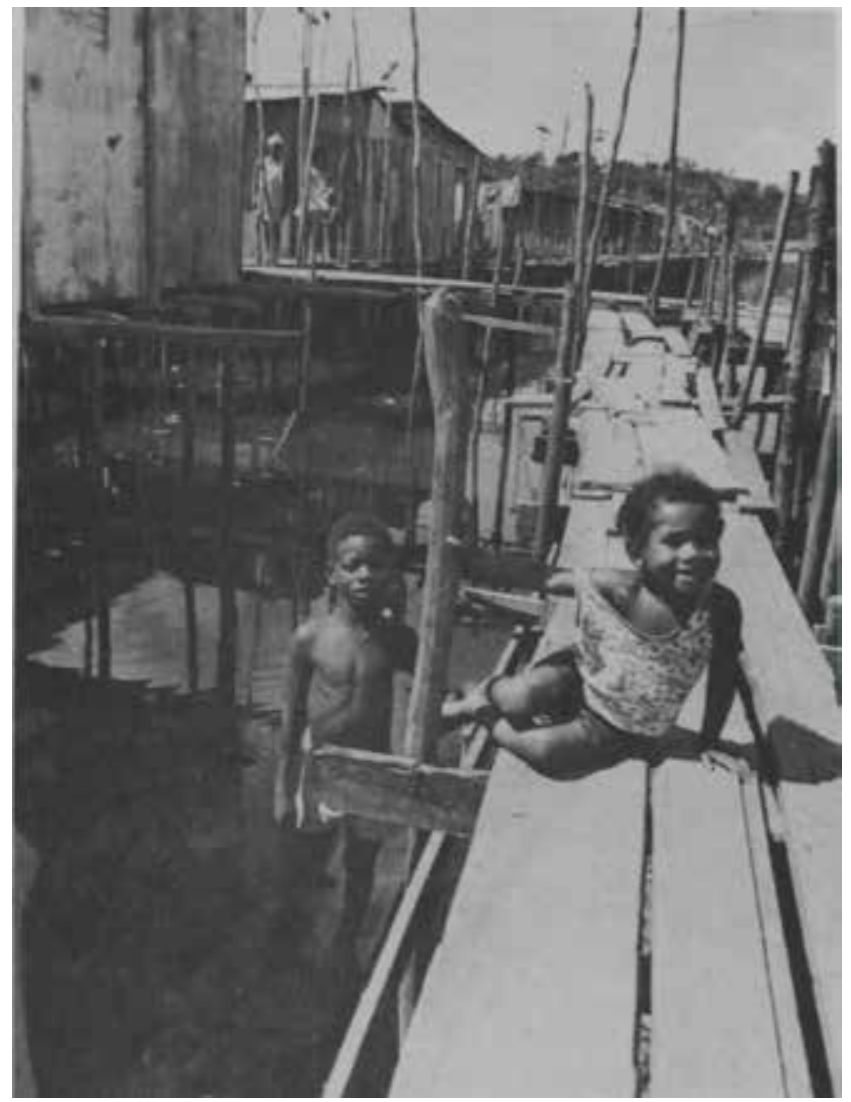

Figura 1 : Foto de Valdir Argolo. In: FotoBahia 80. Salvador: [s; e], 1980.

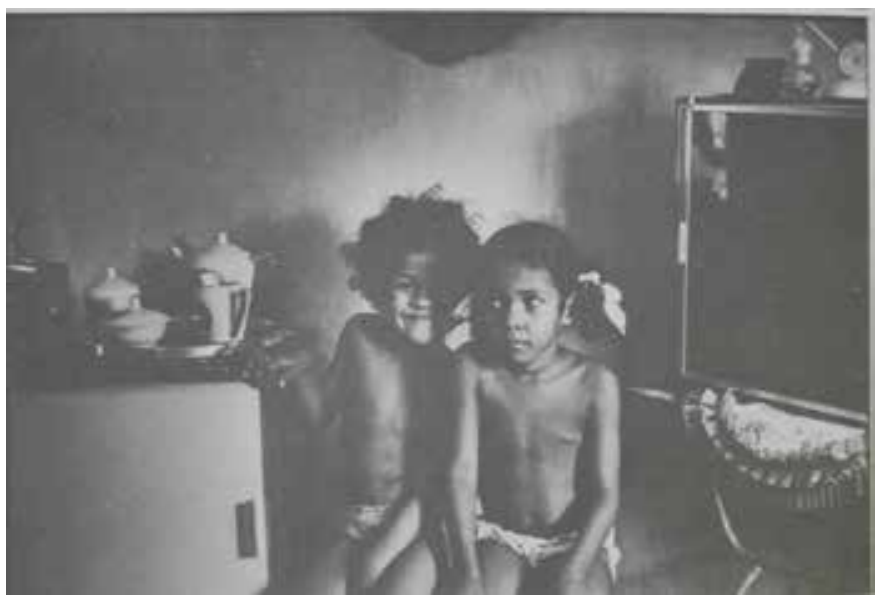

Figura 2 : Foto de Isabel Gouveia. In: FotoBahia 79. Salvador: [s; e], 1979.

Essa interpretação de Mariluce Moura, que é também uma crítica aos limites das escolhas dos fotógrafos, poderia se referir à notável recorrência dos retratos, enquanto gênero, e da infância, enquanto tema privilegiado, que vinha se dando desde os primeiros anos de atividades do Grupo de Fotógrafos da Bahia, nos trabalhos de vários fotógrafos, como se vê na foto de Valdir Argolo e na de uma das fotógrafas que compunha o núcleo fixo do Grupo, a paulistana Isabel Gouveia (Figuras 1 e 2) 3.

3 Por exemplo, em quase todas as fotos da autoria do artista plástico Juraci Dórea encontradas nos catálogos de FotoBahia, aparece o tema da infância. Outro fotógrafo, o juazeirense Euvaldo Macedo Filho, tinha esse tema como uma de suas predileções, e embora não tenha enviado imagens com esse tema para FotoBahia, chegou a enviar trabalho em uma exposição ocorrida no México, chamada "Presença da criança na América Latina", de iniciativa da UNICEF, o organismo internacional de auxílio à infância. Caberia uma investigação particular da recorrência desse tema na poética documental dos fotógrafos que atuaram na crise do fotojornalismo e na abertura para o trabalho documental autoral. Essa investigação pontuaria, decerto, que desde, pelo menos, a exposição Family of the Man, curada por Edward Steichen, no Museum of Modern Art de Nova lorque, em 1955, a infância fora idealizada e demarcada como uma temporalidade que seria universal para todas as culturas. Sabe-se que usar a imagem da infância foi também, de certa forma, metaforizar o estatuto antropológico de sociedades consideradas à margem do Ocidente (cf. LÉVI-STRAUSS, Claude. "Raça e História". In: . Antropologia Estrutural 2. Rio de Janeiro: Tempo Brasileiro, 1987). 
Nos textos de apresentação dos catálogos de outros anos, Mariluce Moura e a também jornalista Symona Gropper procuram vincular o Grupo à trajetória da fotografia na Bahia. Moura, em particular, assina o texto introdutório do catálogo de 1979, com o título "A fotografia na Bahia (apesar das perdas, um retrato nítido de mais de um século)", reiterando a metáfora que se tornou o lugar comum de que a fotografia seria um retrato da sociedade. A jornalista relembra um passado fotográfico que remetia sobretudo ao fotojornalismo, mas também à arte e aos estúdios comerciais, que começavam sua atuação em Salvador, e em seguida, conseguiam chegar até o interior do Estado, ampliando o universo de usos sociais da fotografia. Ao narrar o crescimento da atuação dos fotógrafos junto aos jornais, especialmente o incremento tecnológico que permitiu captar o flagrante, o texto indica ainda a mesma questão profissional lembrada por Alves: os fotógrafos passaram a transitar do fotojornalismo para a publicidade e para a fotografia artística, como campos paralelos de trabalho (MOURA, 1979). O lugar particular de FotoBahia seria confirmar um papel social eminentemente identitário: a fotografia era capaz de "fixar esta cidade [de Salvador] e sua gente. Sua vida e sua alma".

Por sua vez, com o título "Um Retrato sem Retoque", o texto de Symona Gropper, publicado no catálogo de 1980, trazia a mesma metáfora, acentuando a retórica realista da imagem: um retrato sem retoque seria aquele tipo de retrato, feito por fotojornalistas ou não, que fosse cru, sem manipulação. A autora indica qual a importância da fotografia, de seus porquês e intenções: "a fotografia tem uma importante função social que é a de educar", é "uma forma muito mais democrática de transmitir uma mensagem, que é entendida por qualquer pessoa, seja intelectual, analfabeto, estrangeiro". Ou seja, a fotografia, além de educar, era considerada um meio de comunicação social em si mesma. Gropper destacou, ainda, a diversidade de usos da imagem em FotoBahia, para mostrar o trágico, o folclórico, a beleza do Estado, as coisas antigas e preciosas, bem como seus aspectos sensuais e religiosos. Como corolário, a fotografia seria encarregada de denunciar problemas de minorias que não tivessem quem falasse por elas. Este seria o papel privilegiado do fotojornalista, o qual se encontraria próximo dos mais diversos problemas sociais abordados pelos jornais e, por isso, tornava-se uma figura socialmente sensível, por buscar realizar "um trabalho que denuncie as sub-condições de vida do povo brasileiro e, particularmente, do povo da Bahia" (GROPPER, 1980).

Uma inclinação mais propriamente política a esse papel de denúncia social estaria em duas fotos, uma da autoria do fotógrafo Fred Passos, publicada no catálogo de 1980 (Figura 3), e outra de Milton Mendes, publicada no catálogo de 1979 (Figura 4). Ambas as imagens, como a maioria dos retratos de FotoBahia, dialogam com a tradição fotojornalística que deslocou o retrato para os espaços públicos do cotidiano, retirando-o da encenação da pose de estúdio e propondo outras formas de ver a partir do chamado tempo do flagrante, tornado célebre pela reflexão de Henri Cartier-Bresson a respeito do momento decisivo. As duas fotos também jogam com o enquadramento da figuração nos espaços públicos, compondo seja com a cena do evento político (Figura 3), seja com o letreiro de conteúdo político (Figura 4), para deslocar os sentidos da própria política. Na foto de Fred Passos, o enquadramento escolhido não foi o convencional, de ângulo frontal, que certamente reiteraria o ar 
de solenidade trazido pela presença das autoridades. Passos escolheu outro ângulo, a partir do qual se vê um cachorro deitado no chão em primeiro plano, colocando os políticos e autoridades militares em segundo plano. Ao colocar o cão em destaque, e não as pessoas, o fotógrafo contraria uma fórmula de emoções comumente definida nos retratos para conotar a reverência (GINZBURG, 2014). A de foto de Mendes, por sua vez, reitera certa descrença na política partidária que estaria dita no enunciado escrito, ao colocar um uso do espaço urbano por moradores de rua que parecem ignorar a mensagem inscrita no cenário.
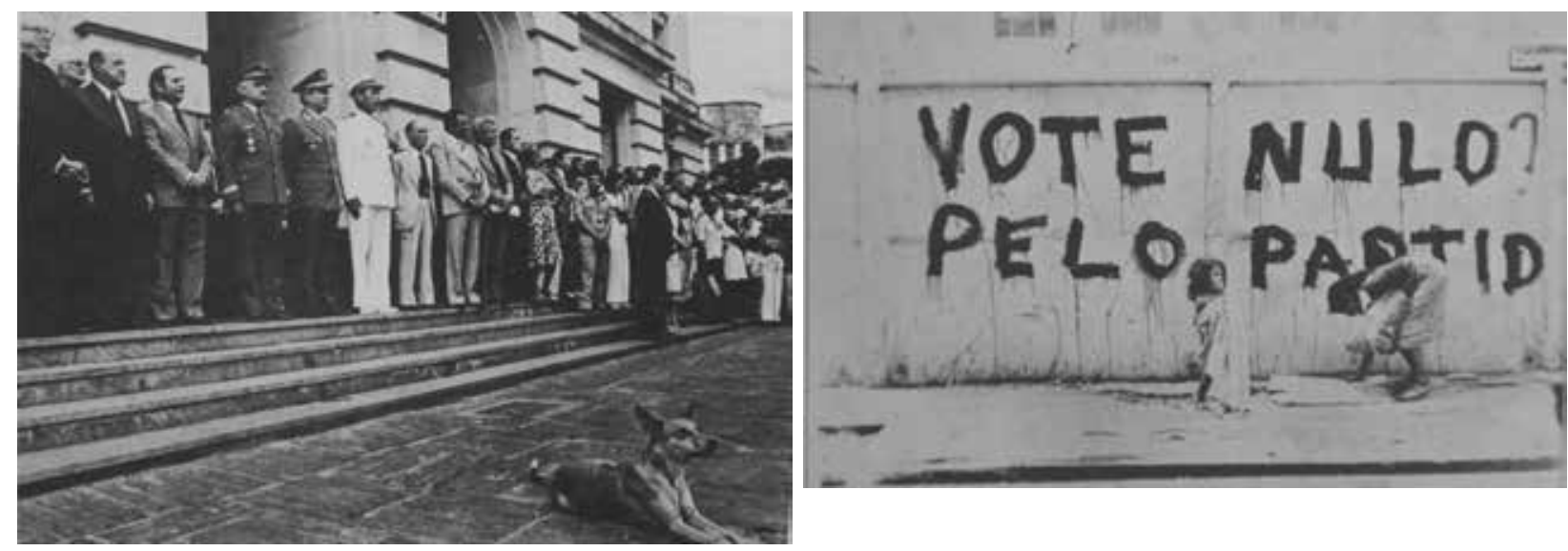

Figura 3 (à esquerda): Foto de Fred Passos. In: FotoBahia 79, Salvador: [s; e], 1979.

Figura 4 (à direita): Foto de Milton Mendes. In: FotoBahia 80. Salvador: [s; e], 1980.

Outra interpretação daquele momento, no entanto, tem enfatizado que, para além do controle político, com a segmentação do mercado veio uma maior amplitude da atuação para os fotógrafos de imprensa, sobretudo com a referida criação das agências e com os trabalhos documentais individuais dos fotógrafos caracterizados por profundo teor investigativo e por uma poética de documentação mais propriamente autoral (MAUAD, 2011). Conforme esta outra interpretação, o "momento crítico" referido por Aristides Alves dizia respeito especialmente à reinvenção do lugar da fotografia, que vinha se dando em outras áreas do país, pela organização em grupos mas também pela abertura de outros espaços discursivos, como os modos de inserção nos museus e galerias, o que já vinha se dando desde pelo menos o surgimento das bienais de arte, como indicamos. Alves complementa com a observação sobre o aumento dos usos da fotografia:

[...] na medida que ela [a fotografia] começa a ocupar espaços de museus, por exemplo, quando nós fizemos a FotoBahia no Museu de Arte da Bahia, era um espaço considerado nobre, de arte, então: como que a fotografia está dentro de um museu? Depois, as pessoas começam a ter fotografia não só como objeto de lembrança de familiares, mas ter uma foto simplesmente como objeto de decoração em casa. Então, essa discussão começa a ter outro tipo de abordagem, porque ela começa a ir pra museu, galeria, é lhe dada uma importância como expressão pessoal (ALVES, 2015).

Daí, entende-se também um pouco melhor a abrangência temática da produção de FotoBahia, que sintetizava as afinidades que cada fotógrafo começava a desen- 
volver com seus recortes sociais: as culturas populares (capoeira, candomblé, festas religiosas), os povos indígenas, os camponeses, o rio São Francisco, os meninos de rua do Pelourinho, a cena do teatro e da dança etc. Exemplo dessas afinidades são as opções e o desenvolvimento do olhar de Adenor Gondim, notabilizado pela poética documental que desenvolveu posteriormente à sua participação em FotoBahia, mas que já contava com larga experiência de trabalho em estúdio comercial, antes de sua carreira autoral. Perguntado pelo tipo de fotos que selecionava para as exposições e catálogos do Grupo, Adenor responde:

Retrato. Eu não consigo me livrar dos dez anos de $3 \times 4$. Uma marca bem significativa no meu trabalho é o retrato. É a cultura popular, é as coisas, eu digo normalmente que o que me encanta é o jeito de corpo e alma das coisas e do povo da Bahia. Não sou fotógrafo de natureza, não sou fotógrafo de animal, não sou fotógrafo de arquitetura. [...]. Agora tem uma coisa, eu fotografo o lado bom da vida. A miséria, a desgraça, a violência, tudo, tem " $n$ " pessoas aí pra fazer, eu não faço (GONDIM, 2016).

Os padrões visuais de um retrato de estúdio, especialmente o de formato $3 \times 4$, destinado ao registro e à identificação do Estado, apresentam sensivel diferença em relação ao retrato marcado por uma poética investigativa ${ }^{4}$, o que nos indica mais uma possível senda de investigação a se adentrar, posteriormente, desta vez a respeito da própria trajetória de um fotógrafo como Adenor Gondim e do que veio a ser incorporado como uma particular conotação antropológica na feitura de suas imagens. Sua fala, entretanto, toca em questões que eram importantes para a época em que ele atuou junto ao Grupo, como o dilema entre a denúncia e a beleza, resolvido numa aposta declaradamente autoral, no seu caso em específico (Figura 7). Por um lado, grande parte das imagens como as de Adenor, a partir inclusive de rememorações como a sua, carregada de uma leitura identitária, atualizavam uma visão considerada típica sobre a Bahia, centrada geograficamente na capital e no Recôncavo baiano e com destaque para as culturas e religiões de matriz afrodescendente - visão que se constituía desde os anos 1930, a partir das interpretações consagradas nas artes e nas Ciências Sociais sobre a mestiçagem e principalmente sobre a negritude brasileira, de que a Bahia seria um espaço exemplar; visão também que era capturada e reinterpretada pelo Estado, pelo turismo e pelos movimentos sociais, nos anos 1970 (AGUIAR, 2008, p. 13-34; SANSONE, 2002).

Por outro lado, assim como a retórica realista voltada para denúncia social era questionada em seus limites, nos trabalhos de outros fotógrafos, o retrato igualmente era tensionado, enquanto forma, no sentido da proposição de outras imagens, não necessariamente identitárias da cultura baiana ou nem mesmo apegadas à representação de determinados sujeitos ou grupos sociais.

\section{Outras margens de experimentação}

Segundo Jean-François Chevrier (2007), nas décadas finais do século XX, o universo da fotografia andava às voltas com mais um capítulo das chamadas "aventuras do quadro", isto é, entre a contestação das formas consagradas de enquadramento

4 Os trabalhos posteriores de Adenor Gondim, especialmente de documentação das Irmandades da Boa Morte, no Recôncavo Baiano, ganharam projeção nacional e internacional dada sua importância para a visualização e afirmação das práticas culturais afrodescendentes dessa área da Bahia. 
da imagem artística e as reinvenções do corte espaçotemporal representado pelo quadro, o qual foi marcante na arte ocidental bem como na legitimação estética da fotografia. Na ambígua acepção da fotografia, cindida entre as belas artes e os meios de comunicação - a exemplo do fotojornalismo -, essas aventuras passavam a sinalizar para a abertura no interior da prática fotográfica à experimentação formal que caracteriza a fotografia documental e a arte contemporâneas. Esse fecundo trânsito criativo no interior do gênero do retrato, inclusive na produção do Grupo de Fotógrafos da Bahia, ainda merece ser investigado, a fim de situar como a definição do que era considerado arte estava se transformando e como a fotografia participava disso, mesmo quando não se propusesse necessariamente artística, numa produção que atualizava o velho debate sobre os processos e produtos da poética artística terem sofrido interferência das lógicas temporais e epistemológicas da fotografia (DUBOIS, 2012; BENJAMIN, 1994).

Vejamos como se lembra Juraci Dórea, um dos integrantes do Grupo que estava entre os chamados "artistas-fotógrafos", e que já vinha transitando para as artes visuais:

Sempre entendi a FotoBahia como um projeto para identificar e valorizar fotografia artística e a foto documental de boa qualidade na Bahia. Ou seja, aquela fotografia que transcendia o mero registro. [...].

Sempre fui atraído e me envolvi com as várias formas de expressão artística. A fotografia passou a integrar meu processo criativo, ao lado da pintura e do desenho, a partir da década de 1970 (DÓREA, 2016).

Embora Dórea defenda uma fotografia aberta à interferência de outras linguagens, os catálogos apresentam imagens suas caracterizadas pela poética documental, seja nos retratos de crianças seja nos retratos de sertanejos com sinais de uma sutil fuga do quadro (Figura 5). Nos trabalhos de outros fotógrafos, como Célia Aguiar, a forma quadro também sofria mudanças com o deslocamento do espaço do rosto na figuração e a busca por um lugar para o corpo nas imagens, a partir de diferentes interesses e temáticas (Figura 6).

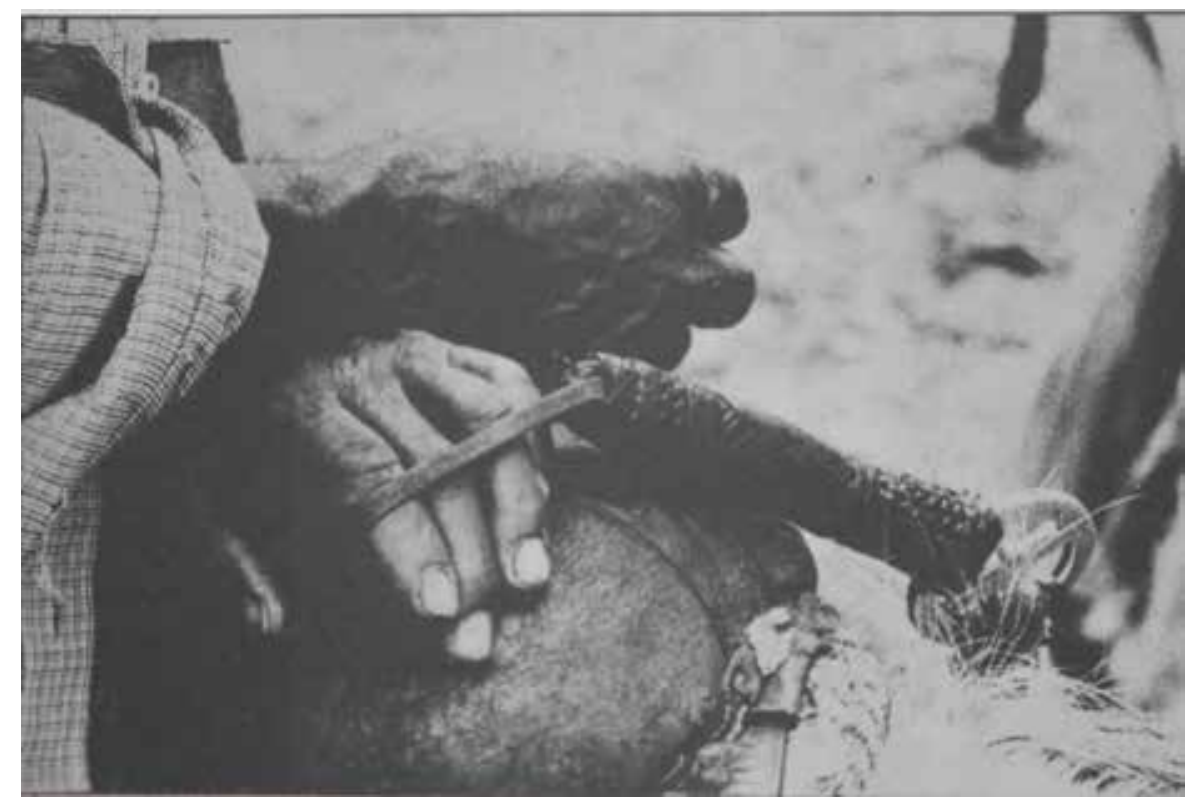

Figura 5 : Foto de Juraci Dórea. In: FotoBahia 79. Salvador: [s; e], 1979 


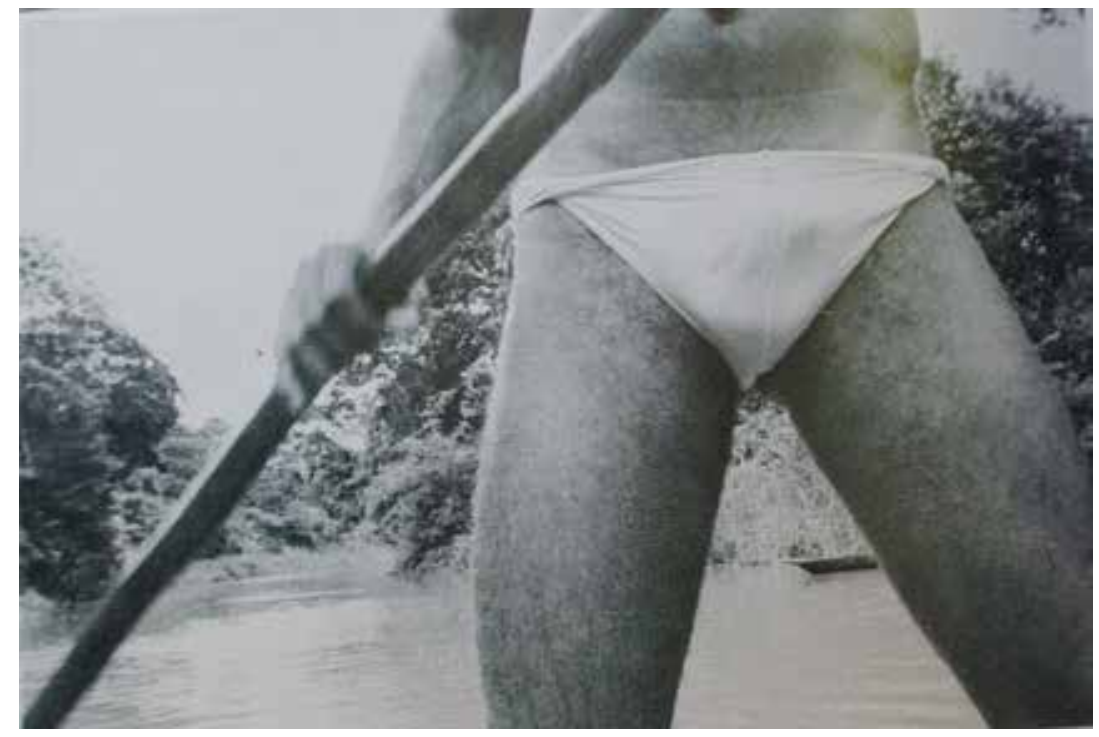

Figura 6 : Foto de Célia Aguiar. FotoBahia 84. Salvador: [s; e],1984.

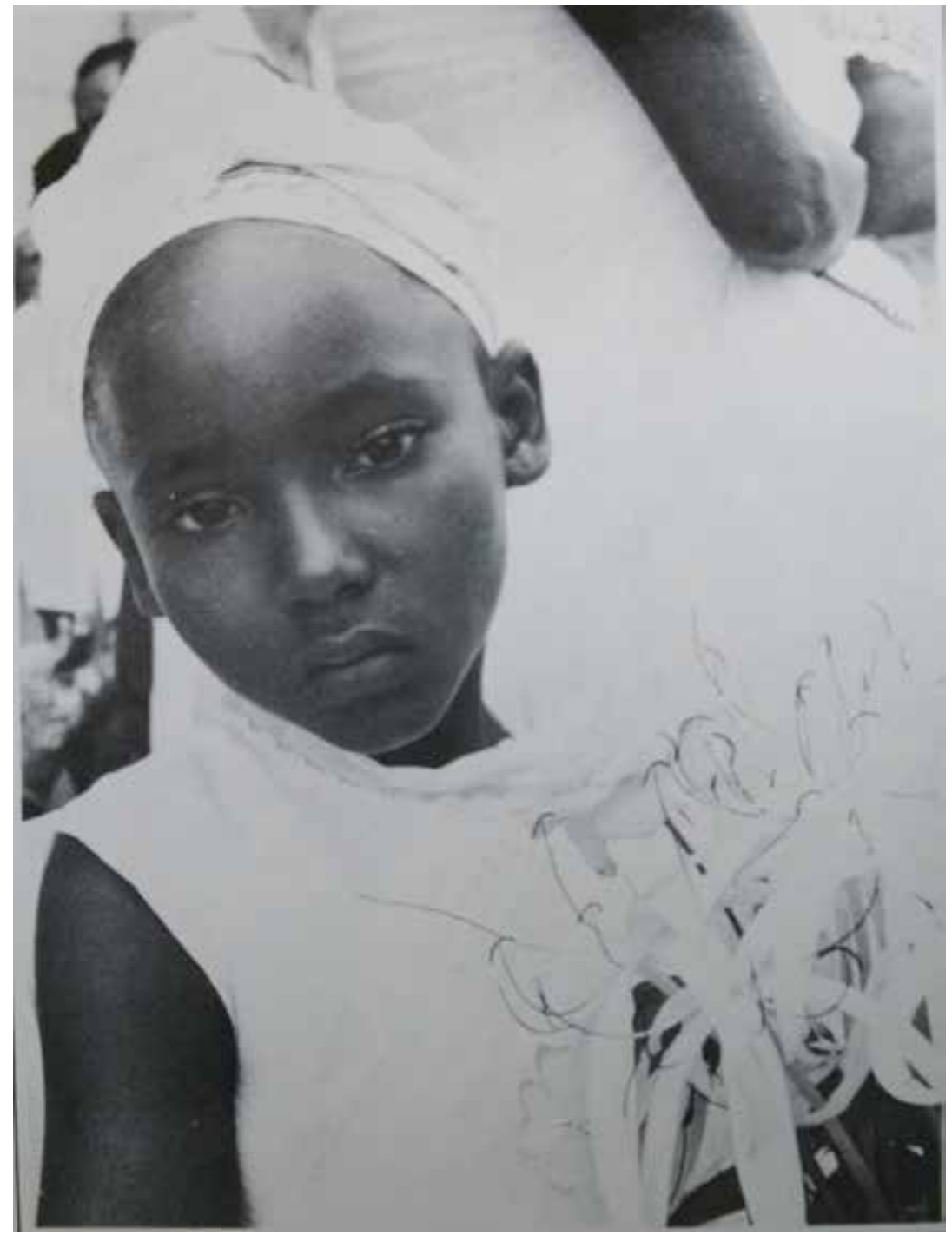

Figura 7 : Foto de Adenor Gondim. FotoBahia 84, Salvador: [s; e],1984. 


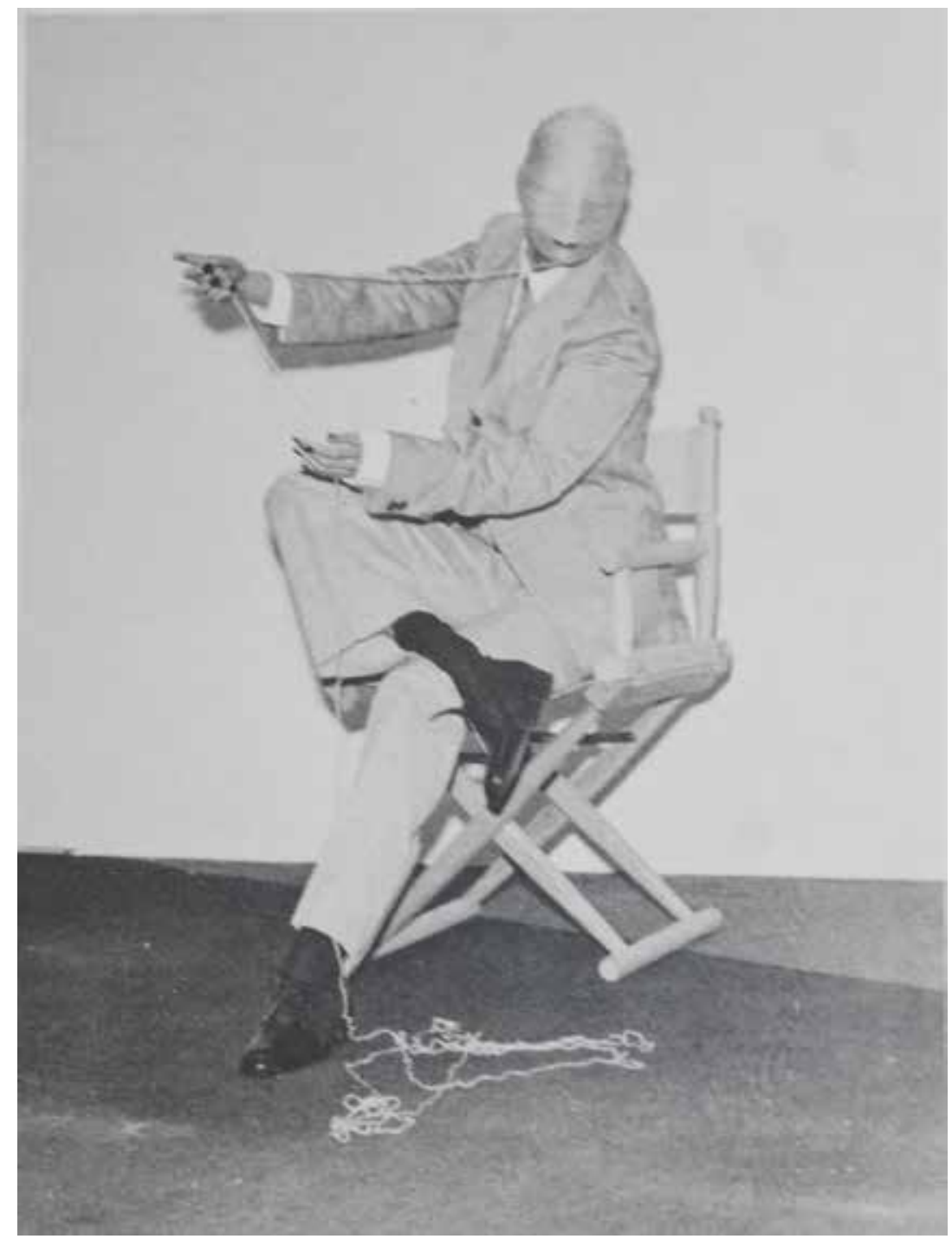

Figura 8 : Foto de Bauer Sá. In: FOTOBAHIA 84. Salvador: s; e, 1984.

Célia Aguiar, fotógrafa iniciante na época de criação do Grupo, mas que já era experiente no fotojornalismo e na conservação fotográfica, lembra da foto de sua autoria (Figura 6), no catálogo de 1984, de sua inclinação expressiva para o retrato e dos critérios que lhe pareciam difíceis quando da seleção da imagem a ser divulgada:

no fotojornalismo eu fui escolher a área de cultura, então eu gostava de fazer retratos, ir ao teatro. Meu público mantenedor de uma determinada época foram muitos artistas da cidade, os atores, as atrizes, os músicos, era com eles que eu gostava de trabalhar. E eu sempre tive uma atração muito grande pelo corpo [...]. E aí quando chegava a hora de escolher o material pra FotoBahia, óbvio que eu queria escolher uma coisa que tivesse fora desses meus outros afazeres. E aí morria, sofria com isso que eu não sabia exatamente, coisa e tal, mas acabava que uma vez ou outra dava certo, por exemplo, essa foto [indicada no catálogo] é minha de 84, bem ousadinha pra época, fez o maior sucesso, então. [...]. Eu acho que, quando o fotógrafo se joga no tema, ele sempre se dá bem, porque é um aprendizado contínuo (AGUIAR, 2016).

Além de Célia Aguiar, um fotógrafo que procurava, mais particularmente, dar outro tratamento para o retrato era Bauer Sá, já manifestando o que veio a carac- 
terizar seus trabalhos posteriores: uma inclinação para aquilo que Tadeu Chiarelli (2002) nomeou de "fotografia contaminada", isto é, uma produção deliberadamente inserida no seio das artes visuais e da plasticidade de suas poéticas ${ }^{5}$. Segundo Chiarelli, tal "contaminação" se dava seja através do deslocamento metalinguístico da linguagem fotográfica para outros usos, de que o grande exemplo seriam os trabalhos de Rosângela Rennó, seja através do registro de práticas como a performance (Figura 8), cujo conceito toma a fotografia para além do próprio registro, na medida em que a performance opera com a iminência ou a transitoriedade do gesto, sendo a fotografia por vezes seu único vestígio de materialidade ou o necessário interlocutor do corpo performático.

\section{Considerações finais}

Ressoa na fala dos fotógrafos entrevistados em nossa pesquisa a contribuição de sua participação no Grupo de Fotógrafos da Bahia tanto para sua trajetória pessoal e para os rumos que cada um tomou no trabalho com a fotografia, quanto para a afirmação de um lugar para a fotografia na sociedade baiana, posterior à crise do fotojornalismo e contemporâneo à maior abertura de espaços expositivos e discursivos, à luta por políticas específicas e ao estímulo a práticas fotográficas diversificadas, como a documentação e a arte contemporânea.

Nessa constelação de fotógrafos e a partir de seus diferentes olhares, o retrato, então, era tido não apenas como gênero herdado da pintura e do fotojornalismo, mas como metáfora daquele lugar social da fotografia - quer ela tendesse à denúncia ou não -, e especialmente como uma forma privilegiada de ver e de construir o ver, como margem de experimentação do que poderia a imagem fazer ao trazer a cena essa diversidade de temas e de olhares. Não obstante terem sido numerosos os participantes de FotoBahia, e sua trajetória posterior ter se diversificado soberbamente, a pesquisa sobre aquele momento da história da fotografia baiana e brasileira ajuda a ampliar nossa compreensão sobre o que os produtores compreendiam em torno de conceitos caros como arte e documento, e sobre a própria fotografia e quais as opções tomadas para dar a ver certas variáveis sociais e culturais. Por outro lado, entender historicamente essa atuação dá vigor à interpretação sobre os processos sociais - criativos e políticos - que hoje são rememorados como tendo contribuído, a seu modo para a reabertura democrática brasileira, para além da mera censura à produção e circulação das imagens.

\section{Referências}

AGUIAR, Célia. Entrevista concedida ao autor. Salvador, 23 de janeiro de 2016.

AGUIAR, Josélia. O corpo das ruas. A fotografia de Pierre Verger na construção da Bahia iorubá. Dissertação (Mestrado em História) - Programa de Pós-Graduação em História, São Paulo, USP. 2008.

5 Para visualização de alguns retratos de Bauer Sá, cf. <http://bauerssa.wixsite.com/bauersa> Acesso em 30 de set. 2016. 
ALVES, Aristides (coord.). A Fotografia na Bahia (1939-2006). Salvador: Asa Foto Ltda., 2006.

Entrevista concedida ao autor. Salvador, 12 de agosto de 2015.

BELTING, Hans. Antropologia da imagem. Lisboa: KKYM, 2014.

BENJAMIN, Walter. Pequena história da fotografia. In: Magia e técnica, arte e política: ensaios sobre literatura e história da cultura. 7a ed. São Paulo: Brasiliense, 1994.

CHEVRIER, Jean-François. Las aventuras de la forma cuadro en la historia de la fotografía. In: La fotografía entre las bellas artes y los medios de comunicación. Barcelona: Gustavo Gili, 2007.

CHIARELLI, Tadeu. A fotografia contaminada. In: Arte internacional brasileira. São Paulo: Lemos Editorial, 2002.

COSTA, Helouise. Da fotografia como arte à arte como fotografia: a experiência do Museu de Arte Contemporânea da USP na década de 1970. Anais do Museu Paulista. São Paulo. v.16. n.2. p. 131-173. jul.- dez 2008.

Palco de uma história desejada: o retrato do Brasil por Jean Manzon. Revista do Patrimônio Histórico e Artístico Nacional. Rio de Janeiro, n. 27. 1998.

DEL CASTILLO TRONCOSO, Alberto. Rodrigo Moya. Una mirada documental. Ciudad de México: Instituto de Investigaciones Estéticas (UNAM); El Milagro; La Jornada, 2011. p. 155-164.

DIDI-HUBERMAN, Georges. La invención de la histeria. Madrid: Cátedra, 2007.

DÓREA, Juraci. Entrevista concedida ao autor. Salvador, 02 de maio de 2016. [Texto escrito enviado por email].

DUBOIS, Philippe. A arte é (tornou-se) fotográfica? In: O ato fotográfico. 14. ed. Campinas: Papirus, 2012.

FALCÓN, Gustavo. Notas, nomes e fatos da fotografia baiana (1950-2006). In: ALVES, Aristides (coord.). A Fotografia na Bahia (1939-2006). Salvador: Asa Foto Ltda., 2006.

FONTCUBERTA, Joan. Indiferencias fotográficas y ética de la imagen fotoperiodística. Barcelona: Gustavo Gilli, 2011.

FOTOBAHIA 79. Salvador: s; e, 1979. 
FOTOBAHIA 80. Salvador: s; e, 1980.

FOTOBAHIA 1983. Salvador: s; e, 1983.

FOTOBAHIA 84. Salvador: s; e, 1984.

FREUND, Gisele. La fotografía como documento social. Barcelona: Gustavo Gili, 2011.

GINZBURG, Carlo. "Seu país precisa de você": um estudo de caso de iconografia política. In: Medo, reverência, terror. São Paulo: Companhia das Letras, 2014.

GONDIM, Adenor. Entrevista concedida ao autor. Salvador, 12 de maio de 2016

GROBET, Lourdes. Imágenes de miséria: folclor o denuncia. In: MARZO, Jorge Luis (Ed.) Fotografia y activismo. Textos y prácticas (1979-2000). Barcelona: Gustavo Gili, 2006.

GROPPER, Symona. Um retrato sem retoque. In: A fotografia na Bahia (apesar das perdas, um retrato nítido de mais de um século). In: FOTOBAHIA 80. Salvador: [s; e], 1980.

KOSSOY, Boris. Mídias: imagens, ideologia, memória. In: Os tempos da fotografia. Cotia: Ateliê Editorial, 2007.

KOUTSOUKOS, Sandra S. M. Negros no estúdio do fotógrafo. Campinas: UNICAMP, 2010.

LÉVI-STRAUSS, Claude. "Raça e História". In: Antropologia Estrutural 2. Rio de Janeiro: Tempo Brasileiro, 1987.

MAUAD, Ana Maria. O olhar engajado: fotografias contemporâneas e as dimensões políticas da cultura visual. ArtCultura. Uberlândia, v. 10, n. 16, p 33-50, jan.-jun. 2008.

"Milton Guran em três tempos". Studium. n. 28, Campinas: UNICAMP, 2011. <http://www.studium.iar.unicamp.br/28/01.html> Acesso em 1 de julho de 2016.

;; LOUZADA, Silvana; SOUZA JÚNIOR, Luciano Gomes. Anos 1980, afirmação de uma fotografia brasileira. In: QUADRAT, Samantha Viz (org.). Não foi tempo perdido. Os anos 80 em debate. Rio de Janeiro: 7 Letras, 2014.

MIRA, Maria Celeste. O leitor e a banca de revista: o caso da Editora Abril. O leitor e a banca de revista: o caso da Editora Abril. Tese (Doutorado). UNICAMP. Campinas, 1997. p. 61-63. 
MONTEIRO, Charles. El campo de la fotografía y las imágenes del Brasil en los años 1970-80: entre el fotoperiodismo y la fotografía documental. Artelogie, n 7, abr. 2015.

MOURA, Mariluce de Souza. A fotografia na Bahia (apesar das perdas, um retrato nítido de mais de um século). In: FOTOBAHIA 79. Salvador: [s; e], 1979.

e/], 1983.

Tempo e real: a miragem da fotografia. In: FOTOBAHIA 1983. Salvador: [s;

SANSONE, Livio. Da África ao afro: uso e abuso da África entre os intelectuais e na cultura popular brasileira durante o século XX. Afro-Ásia. Salvador, n. 7, p. 249-269, 2002.

SANTHIAGO, Ricardo. História oral e as artes: percursos, possibilidades e desafios. História Oral. v. 16, n. 1, p. 155-187, jan./jun. 2013.

SOUSA, Jorge Pedro. Uma história crítica do fotojornalismo ocidental. Chapecó: Argos, Florianópolis: Letras Contemporâneas, 2004.

TAGG, John. El retrato fotográfico y la producción de mercancías. In: El peso de la representación. Barcelona: Gustavo Gili, 2005.

WARBURG, Aby. A arte do retrato e a burguesia florentina. In: A renovação da Antiguidade pagã. Rio de Janeiro: Contraponto, 2013. 